\title{
CHALLENGES OF EUROPEAN INTEGRATION - TO WHAT EXTENT SHOULD THE COMMON AGRICULTURAL POLICY STAY COMMON?
}

\section{Abstract}

The common agricultural policy (CAP) is considered to be the oldest EU policy and one that covers such a vast range of issues that it leaves almost no room for Member States' policy in this field. Yet the recent consecutive reforms which base their rationale on the common truth that "one-size-does-not-fit all" give more and more room for Member States to make their own choices. Thus, both a theoretical and an empirical question can be posed: what is the optimal solution for the EU and its citizens (acting both as consumers and taxpayers) when it comes to shaping agricultural policy? Should it be an EU policy or should it be left to Member States or even to their regions?

This paper presents an answer to the question posed in the title. The answer is based on the theory of fiscal federalism and environmental federalism as well as practical issues relating to the functioning of EU agriculture based on a literature review.

The results show that there is room for activity by both the EU and the Member States when it comes to agricultural policy. The optimal division of tasks between the EU and Member States, based on the subsidiarity principle, shows that EU policy should focus on safeguarding the competitiveness of EU agriculture and fair competition on the EU common market, while Member States should concentrate on fine-tuning EU policy instruments to the specific needs of their agriculture.

Barbara Wieliczko, Institute of Agricultural and Food Economics - National Research Institute, Świętokrzyska 20, 00-002 Warszawa, Poland, e-mail: Barbara.Wieliczko@ierigz.waw.pl, ORCID: https://orcid.org/0000-0003-3770-0409.

This is an open access article distributed under the terms of the Creative Commons Attribution-NonCommercial-NoDerivatives 4.0 License (CC BY-NC-ND 4.0); https://creativecommons.org/ licenses/by-nc-nd/4.0/. 
Keywords: common agricultural policy, EU agriculture, fiscal federalism, environmental federalism, subsidiarity principle.

JEL Classification: Q18, Q58, R11.

\section{Introduction}

The Common Agricultural Policy (CAP) was foreseen by the Treaty of Rome (1957). Yet it was only launched five years later - in 1962. Thus, it has over 55 years of history. It has been changing and evolving ever since its establishment to cater for the evolving needs of the $\mathrm{EU}^{1}$ agricultural sector. However, its treaty objectives have remained the same. They include (Consolidated Version of the Treaty on the Functioning of the European Union 2008, art. 39):

- increasing agricultural productivity by promoting technical progress and by ensuring the rational development of agricultural production and the optimum utilization of the factors of production, in particular labour;

- ensuring a fair standard of living for the agricultural community, in particular by increasing the individual earnings of persons engaged in agriculture;

- stabilizing markets;

- assuring the availability of supplies;

- ensuring that supplies reach consumers at reasonable prices.

In the 1970s and 1980s, CAP was focused on supply management. In this period, farms became so productive that they were producing more food than was needed. This was a result of the high prices offered to farmers, which led to surpluses that were stored as "food mountains".

Excessive supply forced the EU to reshape the CAP in 1992. The price support was almost fully replaced by a system of direct payments. It was supposed to be a temporary compensation for abolishing the price support. Yet it is still in place today.

In the 1990s, the so-called second pillar of the CAP was developed to its current scale and form ${ }^{2}$. It is also called the EU rural development policy, although it focuses predominantly on the agricultural sector. Among the new policy measures introduced in the 1990s were instruments aimed at supporting farm investment, training, improved processing and marketing of agricultural products, and organic farming.

\footnotetext{
${ }^{1}$ For simplification, only the current name of the European Union and its abbreviation are used in this paper.

${ }^{2}$ Each programming period brings some modifications and alterations to the set of measures and the way they are implemented, but the general concept remains the same.
} 
Due to the EU's WTO obligations, in 2003 the CAP underwent another reform. This concerned cutting the link between subsidies and production. Therefore, the support was not based on the scale of production but on the area under farming and was conditional on respecting strict food safety, environmental, and animal welfare obligations and standards (GAEC). It must be stated, however, that all the CAP reforms from the 1990s until 2008 were to a large extent motivated by international trade negotiations and it is even argued that this resulted in the internationalization of agricultural policy (Daugbjerg 2017).

In 2015 another reform of the system of direct payments was implemented. It introduced several new payment categories, among which the most important were payments for agricultural practices beneficial for the climate and the environment, the so-called greening of direct payments. These payments are conditional on fulfilling certain obligations related to agricultural practices that should have a positive impact on the environment. Greening of direct payments is supposed to serve as a justification for supporting farmers as suppliers of environmental public goods.

The plans for the CAP 2020+ go even further in the direction of justifying the CAP's support to farmers and focus on transforming the CAP into an evidence-based policy. At the same time, the European Commission wants to transfer even more power to Member States so that they have a bigger say in designing the shape of the CAP in their respective countries.

Although the CAP's priorities stipulated in the Treaty of Rome have remained unchanged, each programming period has to be in line with the key growth and development priorities of the EU. In the 20142020 programming period, the CAP priorities are (Regulation (EU) No 1305/2013, art. 4):

a) "fostering the competitiveness of agriculture;

b) ensuring the sustainable management of natural resources, and climate action;

c) achieving a balanced territorial development of rural economies and communities, including the creation and maintenance of employment".

For the next programming period, the European Commission (EC) has proposed following specific objectives (European Commission 2018b, p. 11):

- "support viable farm income and resilience across the EU territory to enhance food security;

- enhance market orientation and increase competitiveness, including greater focus on research, technology, and digitalization;

- improve farmers' position in the value chain; 
- contribute to climate change mitigation and adaptation, as well as sustainable energy;

- foster sustainable development and efficient management of natural resources such as water, soil, and air;

- contribute to the protection of biodiversity, enhance ecosystem services, and preserve habitats and landscapes;

- attract young farmers and facilitate business development in rural areas;

- promote employment, growth, social inclusion, and local development in rural areas, including bio-economy and sustainable forestry;

- improve the response of EU agriculture to societal demands on food and health, including safe, nutritious, and sustainable food, as well as animal welfare".

It has been considered the most common EU policy. This is related to the fact that it is a complex policy that applies to all farmers. It also leaves little room for state or regional policy instruments.

The EU treaty clearly states the division of competences related to policy-making in the EU. There are policy areas that are a sole responsibility of the EU (such as trade policy), ones that are shared (such as agriculture and the environment), and ones that are decided exclusively by the Member States. Yet, in a globalizing world with increasing interrelations between companies and citizens, the division of competences may be questioned.

This paper presents an answer to the question posed in the title. The answer is based on the theory of fiscal federalism as well as practical issues relating to the functioning of EU agriculture based on a literature review. Given the specificity of the topic, the theoretical part of the paper is combined with a description of the methodology, that is, a presentation of the key characteristics of the theories of fiscal and environmental federalism.

\section{Fiscal and Environmental Federalism}

The theory of fiscal federalism has been developing since the middle of the $20^{\text {th }}$ century, with key inputs to its development contributed by Musgrave and Oates. Fiscal federalism is concerned with the problem of the most efficient division of tasks among different levels of government. Already from the beginning this theory's development, a normative framework defining the division of tasks between the central (federal) and regional authorities was created. It was pointed out that central government should be responsible for macroeconomic stabilization of the whole country 
and redistribution of income to the poorest regions (Oates 1999, p. 1121). It must be stated that the concept of fiscal federalism has both advantages and disadvantages. According to its proponents, the main advantage is greater efficiency when spending funds (Oates 1999, p. 1122), while the main disadvantage relates to the lack of economies of scale, which can make the task of, for example, tax collection more costly and difficult.

Boadway and Tremblay (2012, p. 1065) mention two key approaches to fiscal federalism. The first of these is the approach inspired by Tiebout. It assumes that the role of regions is to provide public goods of a regional nature in accordance with the preferences of its residents. Central government, on the other hand, deals with the stabilization of the macroeconomic situation. This approach also presents the so-called "decentralization theorem" proposed by Oates.

The second approach emphasizes the heterogeneity of the regions' fiscal possibilities. In addition, it is states that the regions provide not only public goods, but also individual services. Researchers advocating this approach include Musgrave, Scott, and Flatters.

Environmental federalism is related to the problem of fiscal federalism. Moreover, it seeks "ways to reduce the economic and environmental losses associated with the common pool" (Costello \& Kaffine 2018, p. 119). In the case of environmental federalism, the rationale for a centrally conducted policy is clearer given the fact that environmental issues cannot be internalized within the administrative borders of a given state. For environmental federalism, dynamic, interactive or dialogic federalism are advocated. These models of federalism envisage the regulatory jurisdiction of either states or the federal government, "depending upon the multiple dimensions of the problem itself" (Engel \& Rogers 2015, p. 2).

\section{European Agriculture and the CAP}

European agriculture is an important part of global food production. It provides raw material for the EU food industry, which exports products worth over EUR 130 billion outside the EU every year (European Commission 2018a). EU agriculture includes almost 11 million farms. Most of the farms are very small both in terms of land and the economic scale of their activity. A growing problem is the ageing of farmers, with approximately $30 \%$ of them being over 64 years old. Moreover, the number of farms has been decreasing in recent years (Table 1). 
Table 1. Structure of the EU Agricultural Sector

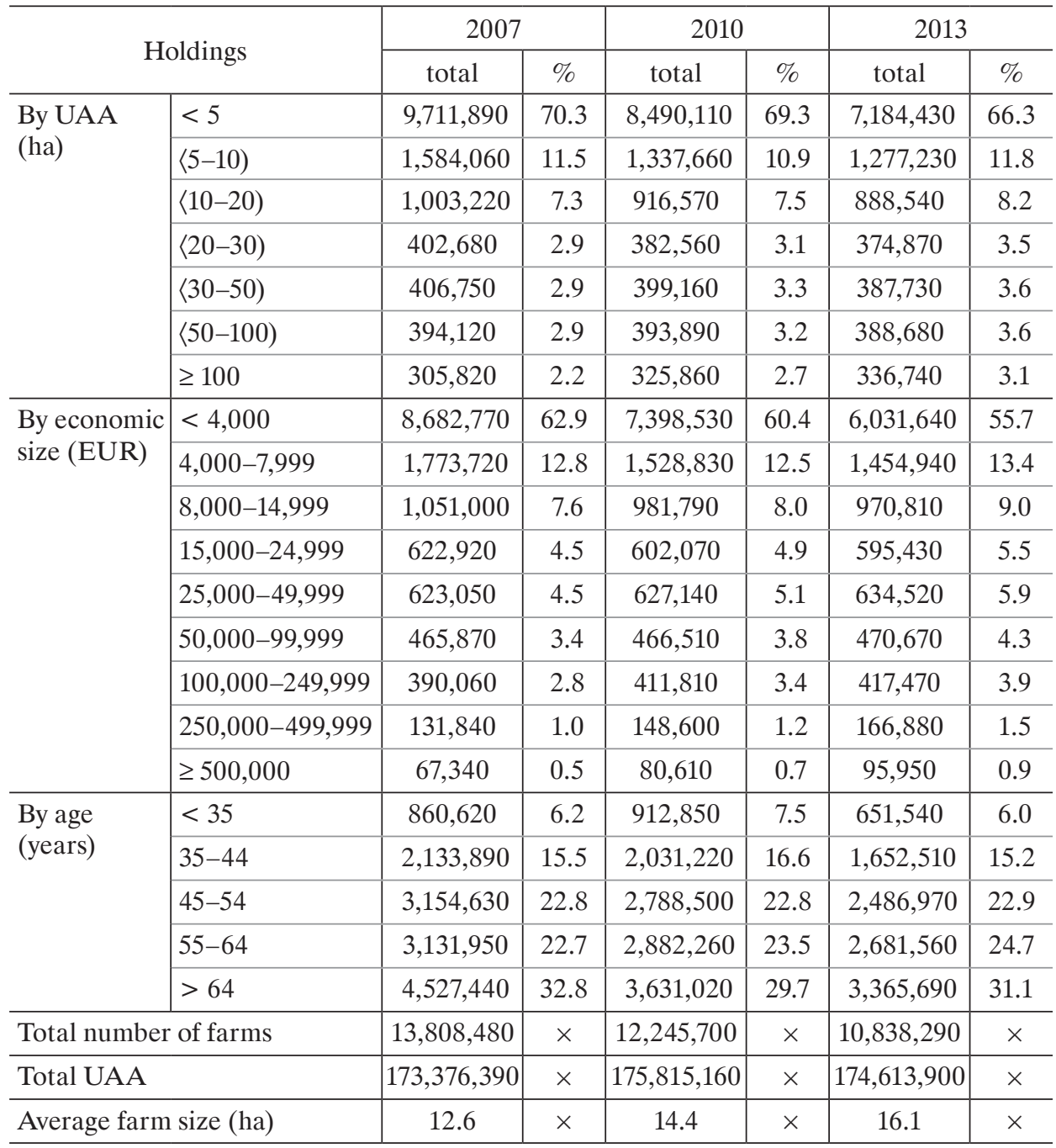

Source: author's own elaboration based on Eurostat data.

However, EU agriculture is far from homogenous. It is characterized by huge diversity given different climatic conditions and historical development. Its diversity is not limited to differences among the EU Member States but also within their national borders. Yet, even an analysis of the key indicators for an average farm shows that there is hardly any similarity among farms in different Member States (Table 2). 
Table 2. Key Characteristics of an Average Farm in the EU Member States (in 2016)

\begin{tabular}{|c|c|c|c|}
\hline Member State & Farm size (ha) & $\begin{array}{c}\text { Standard output } \\
\text { (EUR) }\end{array}$ & Employment \\
\hline Austria & 20.1 & 46,351 & 1.3 \\
\hline Belgium & 36.7 & 217,891 & 0.7 \\
\hline Bulgaria & 22.0 & 18,957 & 0.8 \\
\hline Croatia & 11.6 & 15,134 & 0.8 \\
\hline Cyprus & 3.2 & 17,650 & 2.1 \\
\hline Czechia & 130.2 & 191,555 & 0.3 \\
\hline Denmark & 74.6 & 287,088 & 0.7 \\
\hline Estonia & 59.6 & 47,997 & 0.8 \\
\hline Finland & 44.9 & 70,702 & 0.6 \\
\hline France & 60.9 & 134,371 & 0.6 \\
\hline Germany & 60.5 & 178,361 & 0.6 \\
\hline Greece & 6.6 & 11,059 & 1.5 \\
\hline Hungary & 10.9 & 15,192 & 1.1 \\
\hline Ireland & 35.5 & 45,979 & 0.9 \\
\hline Italy & 11.0 & 45,115 & 1.3 \\
\hline Latvia & 27.6 & 17,465 & 0.9 \\
\hline Lithuania & 19.5 & 14,810 & 1.0 \\
\hline Luxembourg & 66.3 & 185,283 & 0.6 \\
\hline Malta & 1.2 & 10,642 & 1.8 \\
\hline Netherlands & 32.3 & 414,638 & 0.4 \\
\hline Poland & 10.2 & 17,726 & 0.9 \\
\hline Portugal & 14.1 & 19,863 & 0.8 \\
\hline Romania & 3.7 & 3,538 & 2.2 \\
\hline Slovakia & 73.6 & 75,270 & 0.5 \\
\hline Slovenia & 7.0 & 16,578 & 0.9 \\
\hline Spain & 24.6 & 40,598 & 1.2 \\
\hline Sweden & 47.9 & 81,962 & 1.1 \\
\hline United Kingdom & 90.1 & 137,271 & 0.6 \\
\hline EU & 16.6 & 34,785 & 1.1 \\
\hline
\end{tabular}

Source: author's own elaboration based on Eurostat data.

The European Commission strongly advocates the need for a common agricultural policy, stating that "European Union (EU) objectives are better 
achieved by one common policy for the whole EU. Firstly, a common policy makes sure that there is a level playing field and fair competition between farmers. Secondly, environmental problems and climate change do not stop at national borders. Thirdly, a common policy allows for Member States and regions to learn from each other. This is particularly important when it comes to developing the potential of rural areas" (European Commission 2019, p. 7).

\section{What Does the Theory of Fiscal Federalism Say about the Need for a Common Agricultural Policy?}

The question is what level of authority is right for supporting agriculture and rural development issues that are the responsibility of the CAP in the EU. However, it must be borne in mind that, despite the CAP, each EU Member State has its own policy instruments targeted at agriculture and rural areas. In many cases, regions also have their own policy instruments for agricultural and rural development. Therefore, it is worth analysing the division of responsibilities concerning support for agriculture and rural areas.

The EU established a strict set of rules regarding the granting of state aid to farmers. These rules limit the scale and types of public support offered to the agricultural sector. The Member States make different use of this possibility (Table 3).

In the case of the EU, an important legal instrument has been introduced to control the division of powers and responsibilities between the EU and the Member States. This is the subsidiarity principle. It is part of the Treaty on the Functioning of European Union. In the case of agriculture, the responsibility is shared between the EU and the Member States. The delivery of CAP instruments is described in detail in the EU regulations in order to clearly define the division of powers and to ensure that EU public funds are not subject to fraud or other financial misconduct.

When preparing new regulations, the European Commission is obliged to analyse whether the subsidiarity principle has not been breached. The same applies to national parliaments of the Member States, which scrutinise whether or not the EC has changed the balance of power with its proposed regulations.

Yet it is difficult to access where the division of powers should be made. Together with the single market and the process of globalization, the common rules facilitate trade among the EU Member States and the export of EU products to third countries. Therefore, new common rules keep being proposed in order to homogenize the conditions under which farms operate. 


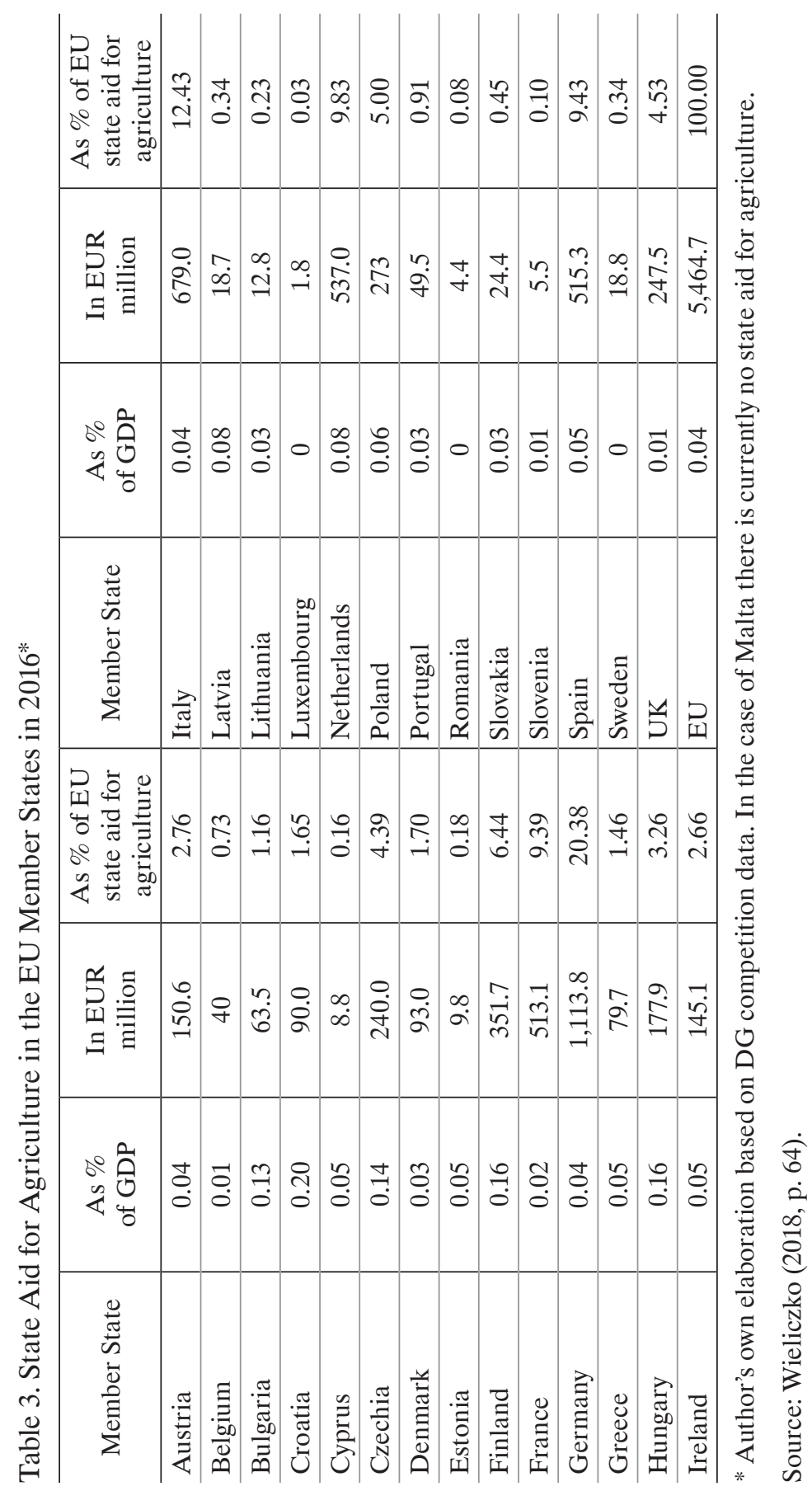


An important issue to be considered when dealing with the question of the need for a common EU agricultural policy is the other side to the budgetary policy, that is, taxation policy towards the sector. "It is surprising that given the strong emphasis on common conditions for competing in the agricultural sector no country or lobby group has ever mentioned the need for homogenous taxes in the agricultural sector" (Wieliczko 2012, p. 156).

In the case of EU agriculture, there are certain pros and cons of having a common policy towards the agricultural sector. The reasons for generally include the existence of common challenges, such as globalization, climate change, and ageing of EU farmers. Moreover, the EU single market requires a level playing field for all economic entities. Therefore, a common agricultural policy can serve as means of ensuring similar operating conditions for all EU farmers. Yet there are also arguments in favour of a more decentralized agricultural policy. These include differences in the economic and environmental conditions under which farmers conduct their economic activity.

As regards the functioning of the CAP in the 2021-2027 programming period, the European Commission has proposed greater powers for the Member States. In the introduction to one of the proposals concerning the future CAP, the EC states that "in the Union's highly diversified farming and climatic environment, however, neither top-down nor one-size-fits-all approaches are suitable to delivering the desired results and EU added value" (European Commission 2018b, p. 3). The EC expects that greater powers for Member States in shaping the CAP will enable support for farms to be tailored to local conditions and needs. The role of the EC will be focused on controlling EU-wide policy objectives.

However, the proposed changes do not explicitly state how the EC will ensure that common objectives are met. Moreover, it is not certain that Member States will be given real power in shaping CAP design and delivery, since the EC will have the final say on whether to accept the Member States' proposals. Therefore, at this stage of preparing future CAP reform, it is not clear whether the changes will result in an actual modification in the division of responsibilities between the EC and Member States and whether these changes will improve the effectiveness and efficiency of the CAP.

The problem of effective and efficient division of responsibilities in the field of agricultural policy is a question that should be periodically reconsidered to embrace the new problems and challenges facing the sector. Nevertheless, it is certain that "in the long run, there is no substitute for centralized standards; they represent the most important mechanism 
of policy diffusion" (Vogel et al. 2010, p. 38). As the experience of environmental federalism in the USA shows, the practice does not follow any theoretical model. It is dependent on the specific issue, hence this model may be called a dynamic one (Engel \& Rogers 2015, p. 12).

\section{Conclusions}

Fiscal and environmental federalism are issues debated both in economics and legal science. An important issue when determining the allocation of power is the question of knowledge of local needs. This is especially important in the case of environmental federalism, where it is even more essential to balance the generation of environmental public goods with other dimensions of socio-economic life at the local level. Yet cooperation is also an important issue as regards delivering effective environmental protection and climate change mitigation and adaptation. The dynamic model for shaping the distribution of competences for agricultural policy in the EU seems to be the right option to balance the need to safeguard the proper functioning of the EU single market with the differences in the situation of the agricultural sector and environmental needs at the regional and local level.

The need for a common EU agricultural policy can be also influenced by the external forces of global trade relations. As Wieliczko states, given the slowdown in globalisation, the impact of this process on reducing the negative impact of the CAP on world trade will be halted and the indirect impact of international factors linked to the maintenance of the strong position of EU agricultural products will increase (Wieliczko 2017, p. 380). This can also undermine the willingness of the EU Member States to undergo long and difficult negotiations concerning the shape of the CAP and the scale of its funding and to opt for national support for farming. This can be exacerbated by differences in the approach towards supporting agriculture visible among the Member States.

Summing up, it may be stated that there is room for activity by both the EU and the Member States within agricultural policy. The optimal division of tasks, based on subsidiarity principle, shows that EU policy should focus on safeguarding the competitiveness of EU agriculture and fair competition on the EU common market, while the Member States should concentrate on fine-tuning EU policy instruments to the specific needs of their agriculture. 


\section{Bibliography}

Boadway, R. and Tremblay, J. F. (2012) “Reassessment of the Tiebout Model”. Journal of Public Economics 96(11-12), https://doi.org/10.1016/j.jpubeco.2011.01. 002.

Consolidated Version of the Treaty on the Functioning of the European Union, Official Journal of the European Union C 115/47.

Costello, Ch. and Kaffine, D. (2018) "Natural Resource Federalism: Preferences Versus Connectivity for Patchy Resources". Environmental Resource Economics 71(1), https:// doi.org/10.1007/s10640-017-0138-3.

Daugbjerg, C. (2017) "Explaining Reform and Reversal of the EU's Common Agricultural Policy, 1992-2013". Journal of Common Market Studies 55(3).

Engel, K. H. and Rogers, J. E. (2015) "Environmental Federalism: A View from the United States". Arizona Legal Studies Discussion Paper 15-28.

European Commission (2018a) Agri-food Trade Statistical Factsheet European Union Extra EU 28.

European Commission (2018b) Proposal for a Regulation of the European Parliament and of the Council establishing rules on support for strategic plans to be drawn up by Member States under the Common agricultural policy (CAP Strategic Plans) and financed by the European Agricultural Guarantee Fund (EAGF) and by the European Agricultural Fund for Rural Development (EAFRD) and repealing Regulation (EU) No 1305/2013 of the European Parliament and of the Council and Regulation (EU) No 1307/2013 of the European Parliament and of the Council, $\operatorname{COM}(2018) 392$ final.

European Commission (2019) The Common Agricultural Policy: Separating fact from fiction. Brussels.

Oates, W. E. (1999) "An Essay on Fiscal Federalism”. Journal of Economic Literature XXXVZZ: $1120-1149$.

Regulation (EU) No 1305/2013 of the European Parliament and of the Council of 17 December 2013 on support for rural development by the European Agricultural Fund for Rural Development (EAFRD) and repealing Council Regulation (EC) No 1698/2005, Official Journal of the European Union L 347/487.

Vogel, D., Toffel, M., Post, D. and Uludere Aragon, N. Z. (2010) "Environmental Federalism in the European Union and the United States". Harvard Business School Working Paper 10-085.

Wieliczko, B. (2012) "Common Agricultural Policy - the Most Common EU Policy the Least Homogenous" in L. Lacina, P. Rozmahel, A. Rusek (eds) Eurozone and Its Neighbors: The Third Year of Crisis. Bučovice: Martin Stř̌̌ž Publishing.

Wieliczko, B. (2017) "The Impact of Global Surrounding on the Common Agricultural Policy" in Nauki ekonomiczne w XXI wieku - wyzwania, dylematy, perspektywy. Międzynarodowe stosunki gospodarcze. Prace Naukowe Uniwersytetu Ekonomicznego we Wrocławiu nr 498, pp. 374-381, https://doi.org/10.15611/pn.2017.498.34.

Wieliczko, B. (2018) "State Aid in the EU Agriculture" in R. Veselica, G. Dukic, K. Hammes (eds) Economic and Social Development. 36th International Scientific Conference on Economic and Social Development "Building Resilient Society" Book of Proceedings, Development and Entrepreneurship Agency, Varazdin, Croatia; University North; Koprivnica, Croatia; Faculty of Management University of Warsaw, 
Warsaw, Poland; Faculty of Law, Economics and Social Sciences Sale, Mohammed V University in Rabat, Morocco, http://ec.europa.eu/competition/state_aid/scoreboard/ index_en.html.

\section{Abstract}

\section{Wyzwania integracji europejskiej - na ile wspólna polityka rolna powinna być wspólna?}

Wspólna polityka rolna (WPR) jest uważana za najstarszą politykę Unii Europejskiej. Jednocześnie obejmuje tak szeroki zakres zagadnień, że prawie nie pozostawia miejsca dla polityki państw członkowskich w tej dziedzinie. Jednak ostatnie reformy opierały się na stwierdzeniu, że ,jeden rozmiar nie pasuje wszystkim” i przyznały państwom członkowskim więcej możliwości dokonywania własnych wyborów. Można więc postawić zarówno pytanie teoretyczne, jak i praktyczne: jakie jest optymalne rozwiązanie dla UE i jej obywateli (działających zarówno jako konsumenci, jak i podatnicy), jeśli chodzi o kształtowanie polityki rolnej? Czy powinna to być polityka UE, czy powinna być ona pozostawiona państwom członkowskim, a nawet ich regionom?

W artykule przedstawiono odpowiedź na pytanie postawione w tytule. Tę odpowiedź oparto na teorii federalizmu fiskalnego i środowiskowego, a także praktycznych zagadnieniach związanych $\mathrm{z}$ funkcjonowaniem rolnictwa UE $\mathrm{z}$ odwołaniem do przeglądu literatury.

Wyniki pokazują, że w ramach polityki rolnej jest miejsce na działalność Unii i państw członkowskich. Optymalny podział zadań między UE i państwa członkowskie, oparty na zasadzie pomocniczości, pokazuje, że polityka unijna powinna koncentrować się na ochronie konkurencyjności unijnego rolnictwa i uczciwej konkurencji na wspólnym rynku UE, podczas gdy państwa członkowskie powinny skoncentrować się na dostosowywaniu instrumentów polityki UE do konkretnych potrzeb ich rolnictwa.

Słowa kluczowe: wspólna polityka rolna, rolnictwo Unii Europejskiej, federalizm fiskalny, federalizm środowiskowy, zasada pomocniczości. 